\title{
BIRDS OF WILDCAT HILL WILDERNESS AREA
}

\section{by Stan Shadick, Saskatoon}

The following 100 species of birds were seen May 22-24, 1971, in or around the Wildcat Hill Wilderness Area by Dr. and Mrs. Jim Jowsey, Mr. and Mrs. Jim Hogg, John Shadick, myself, and by others from Regina, Moose Jaw and Saskatoon:

Red-necked Grebe; Western Grebe; Pied-billed Grebe; White Pelican; American Bittern; Mallard; Pintail; Green-winged Teal; Blue-winged Teal; American Widgeon; Shoveler; Redhead; Ring-necked Duck; Lesser Scaup; Common Goldeneye; Bufflehead; Ruddy Duck; Red-breasted Merganser; Goshawk; Sharp-shinned Hawk; Red-tailed Hawk; Ferruginous Hawk; Marsh Hawk; Pigeon Hawk; Sparrow Hawk; Ruffed Grouse; Sora; American Coot; Killdeer; Spotted Sandpiper; Greater,Yellowlegs; Lesser Yellowlegs; Pectoral Sandpiper; Semipalmated Sandpiper; California Gull; Bonaparte's Gull; Common Tern; Rock Dove; Mourning Dove; Barred Owl; Saw-whet Owl; Ruby-throated $\mathrm{Humming}$ bird; Belted Kingfisher; Yellow-shafted Flicker; Pileated Woodpecker; Yellow-bellied Sapsucker;
Hairy Woodpecker; Downy Woodpecker; Northern 3-toed Woodpecker; Eastern Kingbird; Eastern Phoebe; Least Flycatcher; Horned Lark; Tree Swallow; Bank Swallow; Barn Swallow; Purple Martin; Gray Jay; Blue Jay; Black-billed Magpie; Common Raven; Common Crow; Black-capped Chickadee; Red-breasted Nuthatch; House Wren; Brown Thrasher; Robin; Hermit Thrush; Starling; Warbling Vireo; Black - and - white Warbler; Orange-crowned Warbler; Yellow Warbler; Chestnut-sided Warbler; Blackpoll Warbler; American Redstart; House Sparrow; Western Meadowlark; Yellow-headed Blackbird; Redwinged Blackbird; Baltimore Oriole; Brewer's Blackbird; Common Grackle; Brown-headed Cowbird; Rose-breasted Grosbeak; Evening Grrosbeak; Purple Finch; Pine Grosbeak; Pine Siskin; American Goldfinch; Red Crossbill; Savannah Sparrow; Vesper Sparrow; Slate-colored Junco; Chipping Sparrow; Claycolored Sparrow; Harris' Sparrow; White - throated Sparrow; Lincoln's Sparrow; Song Sparrow.

\section{YELLOW-THROATED WARBLER SIGHTING AT WEYBURN}

\section{by Robert Kreba, Weyburn}

The Yellow-throated Warbler (Dendroica dominica) has apparently never been reported in Saskatchewan and it is a rare bird in Canada. Godfrey (1966) records a single specimen from St. John's, Newfoundland and two sight records from Niagara Falls and Manotick in southern Ontario; he warns: "To be identified in Canada with caution."

I wisin to report a sighting of a pair of Yellow-throated Warblers at about 6:30 a.m. on May 16, 1970 at Weyburn, Saskatchewan. That day there was only a slight morning chill, and at 9:00 a.m. it was already too warm to wear a coat. The sky was for the most part clear, with some cloud along the horizon, especially in the southwest. Clouds to the east occasionally blocked full sunlight, but only for brief periods, and the wind was low.

Most of my observations that morning were made in the southeast section of the city and the surrounding marshes and countryside. Observations were made with 7 X 35 power binoculars. I first noticed the two warblers from a distance of about 10 yards in a low bush in a row of large trees beside the Souris River. This was in Riverside Park, a campground on the outskirts of the city with no surrounding streets or houses. 
As Myrtle Warblers had been abundant that morning I paid little attention to the two birds at first, assuming that they were Myrtles. A moment's observation, however, made two things immediately obvious: lack of a yellow rump-patch, and the fact that the throat and upper chest were bright yellow, not white with the typical black breast band of the Myrtle. Closer inspection revealed other diagnostic markings: black mottling along the flanks, a white superciliary stripe as well as a white patch behind the ear coverts, two wing bars, and tail spots. The absence of the Myrtle's yellow crown and flank patches further aided in clinching the identification of the two warblers as Yellowthroated Warblers. The white head markings, yellow (not orange) throat and chest, and white wing bars (not a wing patch) distinguished them from the similar Blackburnian Warbler.

My companion that morning, Farrell Hall of Weyburn, also observed most of these features as I pointed them out to him, and we both agreed that the birds matched Singer's illustration in our Birds of North America (Robbins et al, 1966: 265). When I got home I checked other reference books and these further confirmed the identification.

The two Yellow-throated Warblers were tame and relatively inactive, moving along the branches in a somewhat creeper-like fashion, unlike the sprightly activity of the Myrtle and Yellow warblers. These two birds never sang while under observation, although other birds in the vicinity were in full song.

How these warblers (which were probably a pair, although it's difficult to distinguish the sexes in this species) got as far north of their range as Weyburn is a mystery. Griscom and Sprunt (1957), Pough (1949), and Robbins et al (1966) give the most northern limit of distribution of this species as southern Wisconsin. This would mean that a distance of over 1500 miles, on a direct line from Weyburn to Wisconsin, would have had to have been travelled by these birds. If, as is possible, they originated from the western population of the species, of which the northerly limit is southeastern Nebraska, they would have had to travel even further.

Recent years have shown an increase in the number of sightings of warblers of similar eastern ranges, such as the Prothonotary, Bluewinged, Golden-winged and Parula warblers. Perhaps this sighting is further support of the possibility that these eastern species are gradnally extending their ranges westward. It seems more likely, however, that this was just a case of migrants overshooting the mark. It would be interesting to know whether any other sightings of this species were made in this region last year.

\section{LITERATURE CITED}

Godfrey, W. E. 1966. Birds of Canada. Natl. Mus. Can. Bull. 203, Ottawa.

Griscom, L., and A. Sprunt, Jr., 1957. The warblers of North America. Devin-Adair Co., New York.

Pough, R. H. 1949. Audubon land bird guide. Doubleday and Co., Garden City, N.Y.

Robbins, C. S., B. Broun, H. S. Zim and A. Singer. 1966. Birds of North America. Golden Press, New York.

\section{ANOTHER SASKATCHEWAN COLONY OF FORSTER'S TERN}

by Wayne and Don Renaud, Rosetown

The list and accompanying map in the article by Gerrard and Whitfield (Blue Jay, 29:19-22) did not include an important colony of Forster's Terns on Jackfish Lake, although two other smaller colonies were recorded in nearby locations (one at a marsh south of Murray Lake in 1935, and one at a marsh 10 miles north of Meota in 1959). On July 3 and 4, 1970, we explored a colony located in a small, marshy bay about three-quarters of a mile south-southwest of Aquadeo Peach, and located at least 37 nests. Most of the nests were empty, but some contained eggs or young. We do not believe that we found all the nests, for the colony appeared to extend beyond the portion that we searched. Judging by the number of adults, we estimated that the colony had between 50 and 100 pairs of terns - which would make it one of the largest Forster's Tern colonies in Saskatchewan. 